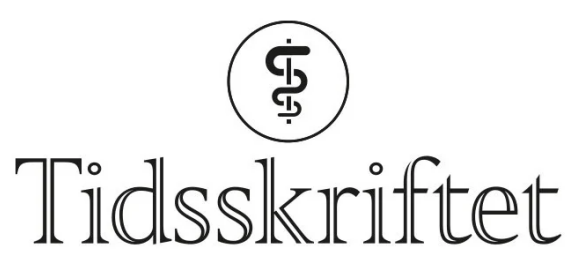

DEN NORSKE LEGEFORENING

\title{
Nevroviten og psykiatri
}

KRONIKK

FINN MAGNUSSEN

Finn Magnussen (f. 1925) er pensjonert lege og spesialist i psykiatri. Forfatter har fylt ut ICMJE-skjemaet og oppgir ingen interessekonflikter. Email: fi-mag@online.no

Den betydelige utviklingen innenfor nevrobiologien de siste par generasjoner er i ferd med å gi et skifte i forståelsen av den menneskelige natur. Dette skiftet er like stort som da det freudske tankeunivers vokste frem i begynnelsen av forrige århundre. For begge disse begrepsverdener gjelder at de har perspektiv og innflytelse langt utover den kliniske verden.

Nevrobiologi er i utgangspunktet «bare» en laboratorievitenskap, som for alvor fikk vind i seilene med utviklingen innen molekylærbiologi og bildefremstillingen av nevrale hendelser. Psykoanalysen er «bare» en behandlingsform for psykiatriske pasienter. Men begge disse arbeidsfeltene har vist seg å ha en kulturell dynamikk som påvirker samfunnslivet, fra filosofi og kunst til økonomi og reklame. Det er fordi de hver på sin måte åpner for en dypere forståelse av den menneskelige natur.

For en psykiater har det dreiet seg om ny innsikt i psykopatologi, ikke minst psykofarmakologisk, da vi lærte om synapser og transmittere. I Norge skjedde det i etterkrigsårene, pussig nok omtrent samtidig med at Freuds tanker og de psykoterapiformer som de inspirerte, vant innpass i psykiatrien. Tilsynelatende står disse to begrepsverdener i et motsetningsforhold til hverandre, til dels er de oppfattet som konkurrerende.

Men det er bare tilsynelatende, for de har begge til felles at de erkjenner hjernen som åstedet: «mind is brain», og omvendt. Sjelen er ikke lenger med i denne erkjennelsesverden, den blir igjen i en religiøs eller poetisk verden. Og motsetningsforholdet mellom psyke og soma er blitt mer irrelevant. Vi er på mange måter på vei inn i en ny psykosomatisk tid, men på et atskillig mer avansert nivå enn i årene fra 1920 til 196o, da vi hadde vår første psykosomatiske æra.

Men forskjellen er der fortsatt. Biologien beskriver sine funn og bygger opp sine teorier ut fra nevrale strukturer og prosesser, nå også på et molekylært nivå, mens psykiatri og psykoanalyse har sinnet ("the mind»), med følelser og tanker som sitt operative nivå. Og 
der kommer også hele den sosiale og kulturelle virkelighet med i bildet, slik den måtte ha avleiret seg i hjernen.

Psykiatriens oppgave er pragmatisk å hente ut forståelse og behandlingsmuligheter der det finnes. Det var Georg Engel som i 196o formulerte dette som den biopsykososiale modellen som rammeverk for psykiatrisk diagnostikk og behandling (1).

Nevrobiologisk innsikt dreier seg om langt mer enn psykopatologi, slik psykoanalysen også er kommet til å dreie seg om langt mer enn terapi. Det dreier seg om vårt menneskebilde, om hvordan vi skal forstå oss selv.

Man kan også se den nye nevroviten som et nytt steg i den tilsynelatende nedgraderingen av mennesket som har skjedd helt fra Kopernikus og Galileo gjorde oss små i universet, og Darwin plasserte oss i dyreriket. Nå er vi ikke engang helt herrer i eget hus, men styres av en hjerne som bare delvis er seg bevisst hva den gjør. Men samtidig begynner vi i større grad å forstå hvor ufattelig kompleks og effektiv denne hjernen er.

\section{Fra psyko til nevro}

Nevrobiologien har i de senere år gitt oss en verden der prefikset psyko erstattes av prefikset nevro, som uttrykk for at det snarere dreier seg om det som skjer fysisk i hjernen, enn det som skjer i sinnet, på det vi er vant til å kalle et mentalt plan. Det reiser spørsmål om, og har følger for, hva vi forstår med begrep som bevissthet og fri vilje, som ellers har vært filosofiens domene. I sin ytterste konsekvens har det også politiske aspekter: Hva eller hvem er det som styrer oss? Er det hjernen, og hvem kan i så fall manipulere den? Eller må vi holde oss til sinnet for å finne basis for å håndtere størrelser som ansvar, frihet og regulering av sosiale relasjoner?

Alle synes å være enige om at det meste av vårt nevronale reservoar er ubevisst, inkludert det Freud beskrev som fortrengte, uaksepterte drifter. Bare en mindre del av det når frem til bevisstheten, men likevel oppleves alt som vår identitet, vårt selv. Noen nevrovitere gir bevisstheten rollen som et slags sanksjonerende organ, som man har kunnet vise at reagerer millisekunder etter at impulsen har oppstått i det ubevisste. Da er vi ikke så langt fra de freudske instanser id, ego og superego.

Det ligger i nevrovitenskapenes perspektiver og ambisjoner at utforskingen av hjernen i stigende grad også vil være med å definere hva vi mener er menneskelige verdier. Om vi noensinne vil kunne forklare hvordan elektriske og biokjemiske reaksjoner i nevroner kan transduseres til subjektiv mening, følelse, tanke og opplevelse, er fortsatt uklart. Spørsmålet er til sjuende og sist om hjernen kan forstå seg selv med seg selv som verktøy. Antakelig, og forhåpentlig, vil fri vilje, empati, glede, sorg, kjærlighet og hat forbli fenomener i sin egen rett, uansett cerebralt korrelat.

\section{Nevroskeptikere}

Fire bøker fra 2013, alle utgitt i USA, har til felles at de har en noe kritisk holdning til den fremadstormende nevroforskningen (3)-( $\underline{6}$ ). Uten å være uenig i selve ideen om at det er verdifullt å forstå mer av hjernens strukturerer og prosesser, er de på forskjellig grunnlag skeptiske til noen nevroviteres overmot og for raske konklusjoner. Jeg blir minnet om Charles Percy Snows foredrag i 1959 om de to kulturer som aldri kan møtes: humaniora, som er vitenskap per intensjon, og naturvitenskap, som er vitenskap per metode (ㅁ).

I psykiatrien ble dette særlig aktuelt fra 1960-årene, da de sosiale faktorer for alvor begynte å prege faget, som tradisjonelt hadde vært biologisk orientert. Da snakket vi om reduksjonisme som noe negativt; «reduksjon» av psykisk liv og psykopatologi til målbare fysiologiske fenomener uten at man brydde seg så mye om det spesifikt menneskelige. I dag er det lettere å se at en «nevroanalyse» også kan bli verdifull, som en psykoanalyse kan 
være det, hver på sine premisser og til sine formål. Nevroforskningens endelige mål synes å være å finne en bro over gapet mellom hjerne og sinn, et felles språk, men det er hverken gitt at det er mulig eller spesielt nyttig.

Den minst skeptiske av forfatterne er filosofen Patricia Churchland (3). Hun balanserer sofistikert mellom tvil og tro, med stor beundring for «nevrosentrismens» fors $ø$ k på å forklare moral, omsorg, empati og fri vilje som uttrykk for evolusjonære erfaringsprosesser nedfelt i hjernen, noe som igjen gir grunnlag for en pragmatisk aksept av selvets ansvar og kontroll.

Sosiologen Nikolas Rose og vitenskapshistorikeren Joelle M. Abi-Rached fra Harvard går nevroforskerne grundig etter i sømmene fra et akademisk ståsted (4). De er opptatt av at nevroforskningen nå er kommet ut av laboratoriene og begynner å få en samfunnsmessig rolle, både økonomisk og potensielt sosiopolitisk. De er kritisk vennskapelige til de implikasjoner det kan ha for samfunnsvitenskapene, der personligheten er enheten, og mener at det er filosofisk feil å tilskrive hjernen kapasiteter som bare et sinn kan ha, som fri vilje, ansvar og handlingsevne. Slik de formulerer seg, er ikke mennesket en hjerne, det har en hjerne.

Den mest skeptiske er nevrologen Robert A. Burton (5). Han tror at skillet mellom sinn og hjerne alltid vil være der. Det er to ulike nivåer i personligheten; hjernen er en konkret fysisk enhet, sinnet er en psykologisk abstraksjon.

Psykiateren Sally Satel og psykologen Scott O. Lilienfeld gir den beste oversikt over feltet slik det spiller seg ut særlig i USA, ikke først og fremst klinisk, men i samfunnslivet, fra filosofi til reklame ( $\underline{6})$. Forfatterne minner om at det ikke er noe nytt at det skjer noe i hjernen når vi føler og tenker. De advarer mot å bli forført av de nye teknologiene, særlig den lettvinte fortolkningen av nevroviten, som de kaller "mindless neurocraty». Vi vet etter hvert mye om hvor og hvordan hjernen reagerer, men lite om hvorfor, om motiver og årsaker. Det siste er størrelser som det er lettere, og antakelig også mer hensiktsmessig, å definere på et annet nivå.

\section{Nevropsykiatri og psykopsykiatri}

Siden min studietid har vi lært mye om hvordan hjernen er plastisk, at den kan endre seg, etablere nye nettverk og programmere seg på basis av hvordan vi oppfatter vår omverden. $V i$ vet også mer om sammenhengen mellom hjerne og sinn. Men den ultimate utfordringen, å forklare bevisstheten som cerebralt fenomen, er fortsatt uløst. Sinnet, det mentale plan, er fortsatt psykiatriens hovedarena. For en kliniker er likevel ikke det største problemet å måtte operere i to ulike begrepsverdener, men å finne den forståelsesform som gir den beste behandlingen.

Tradisjonelt har psykiatrien vært forankret i teorier om genetikk og cerebral dysfunksjon. Freuds utvikling av et mentalt univers på psykologisk nivå kom som en utvidelse av den psykiatriske verden, både innholdsmessig og som virkefelt. Det gjaldt ikke bare symptomforståelsen, de nye psykoterapiformene og mulighetene for forebygging. Det som på sikt kanskje har størst klinisk verdi, er erkjennelsen av pasient-terapeut-forholdet som sentralt verktøy i behandlingen, og betydningen av klinisk kompetanse. Det er en sentral oppgave å bevare og videreutvikle dette også når vi får nevrovitenskapenes nye kunnskap å hanskes med. Noen psykiske lidelser, særlig de alvorligste, kan selvsagt bli lettere å behandle om vi får gode biologiske markører. Men det er viktig å ha med seg at det alltid også er mennesker i en gitt sosial verden og kultur vi forholder oss til, ikke bare syke hjerner.

Det finnes kanskje noen nevropsykiatere som vil se seg som hjernens indremedisinere, men det er så langt uvanlig i vår verden. Og nevrologene synes ikke å orientere seg i retning av å fange opp det store volumet av psykiske lidelser. Men Freud, den tidligere 
nevropatologen, ville antakelig vært med på den ferden. Hans psykoanalyse ble ingen "nevroanalyse», fordi det ikke var metoder og begrep tilgjengelig i hans tid.

\section{Nevro-psykoanalyse?}

Eric Kandel er kanskje den som tydeligst har sett hvordan noen av psykoanalysens begreper og innsikter er forenlig med moderne nevroviten (.7.). Han fikk nobelprisen i 2000 for sin utforsking av hukommelse og læring, som han mener er viktige biologiske prosesser også i psykoanalytisk sammenheng (7.). Kandel, som begynte sin utdanning som psykoanalytisk orientert psykiater, beklager psykoanalytikernes manglende evne eller vilje til å ta vare på sin empiri og til å utforske terapiformens egenart og behandlingsresultater. Han ser for seg at nevrobiologisk forståelse kan komme til å gi grunnlag for bedre indikasjoner og rammer også for denne behandlingsformen. Det er klinikerne som kan formulere de spørsmål som nevroviterne skal søke svar på. Kandels sans for det psykodynamiske kommer enda tydeligere frem i hans siste bok, som tar ham tilbake til hans gamle hjemby Wien og til det kunstneriske og vitenskapelige miljøet der i årtiene rundt $1900(\underline{8})$. Han minnes logoen på Apollon-templet i Delfi: «Kjenn deg selv», en filosofisk utfordring som i dag synes overtatt av nevrovitere. Kandel har selv bidratt til å forene biokjemi, genetikk og cellebiologi i en molekylær nevrobiologi. Han ser for seg en videre felles streben av både kunst og vitenskap for å forstå menneskers bevisste og ubevisste liv, og sammenlikner denne streben med fysikernes fortsatte søken etter en felles forståelse av universets energiformer.

\section{Psykiatriens skjebne}

Den kliniske psykiatrien kommer noe i skyggen av slike overordnede problemstillinger, men har selvsagt all interesse av å nyttiggjøre seg den kunnskapen nevrovitenskapene kan gi. Vi befinner oss i praksis på det mentale plan når vi forholder oss til mennesker med psykiske lidelser. Og det er egentlig lite erkjent at der har vi faktisk, på vårt beste, noenlunde uanstrengt samkjørt de to kulturene humaniora og naturvitenskap, og også fått med oss sosiale årsaker og samfunnsmessige hensyn. Kanskje det er vår ars medica - vårt bidrag til den felles streben nevnt ovenfor?

Når vi iblant har vært opptatt av profylakse eller mentalhygiene, av hva som på sosialt plan skaper uhelse og helse, har vi møtt grenser, ikke bare for vår egen kompetanse, men også for samfunnets interesse for og prioritering av slik innsikt. Vi ble ikke de sosiale ingeniørene som noen tenkte seg i 1970-årene. Og kanskje er det like bra. Den nye nevroviten åpner i prinsippet for overvåking og intervensjoner som minner om det digitaliseringen allerede muliggjør på individplan. Det kan være svært nyttig å vite om en hjernes utviklingsmuligheter, men det er vanskelig å forvalte slik kunnskap, som kan skape like mye problemer som den løser. Hvis vi finner det gode grep på denne utviklingen, vil vi ha en ny psykosomatisk medisin, og den kartesianske dualisme vil bli enda mer historisk.

LITTERATUR

1. Engel GL. A unified concept of health and disease. Perspect Biol Med 196o; 3: 459-85. [PubMed]

2. Snow CP. The two cultures and the scientific revolution. Cambridge: Cambridge University Press, 1959.

3. Churchland PS. Touching a nerve. The self as brain. London: W.W. Norton \& Co, 2013.

4. Rose N, Abi-Rached JM. Neuro: The new brain sciences and the management of the mind. Princeton, NJ: Princeton University Press, 2013.

5. Burton RA. A sceptics guide of the mind. New York: St. Martin's Press, 2013.

6. Satel S, Lilienfeld O. Brainwashed. The seductive appeal of mindless neuroscience. New York: Basic Books, 2013. 
7. Kandel ER. In search of memory. The emergence of a new science of mind. New York: W.W. Norton $\&$ Co, 2006.

8. Kandel ER. The age of insight. The quest to understand the unconscious in art, mind and brain, from Vienna 1900 to the present. New York: Random House, 2012.

Publisert: 14. oktober 2014. Tidsskr Nor Legeforen. DOI: 10.4045/tidsskr.14.08o8

Mottatt 20.6. 2014 og godkjent 29.6. 2014. Redaktør: Are Brean.

(C) Tidsskrift for Den norske legeforening 2023. Lastet ned fra tidsskriftet.no 26. april 2023. 